
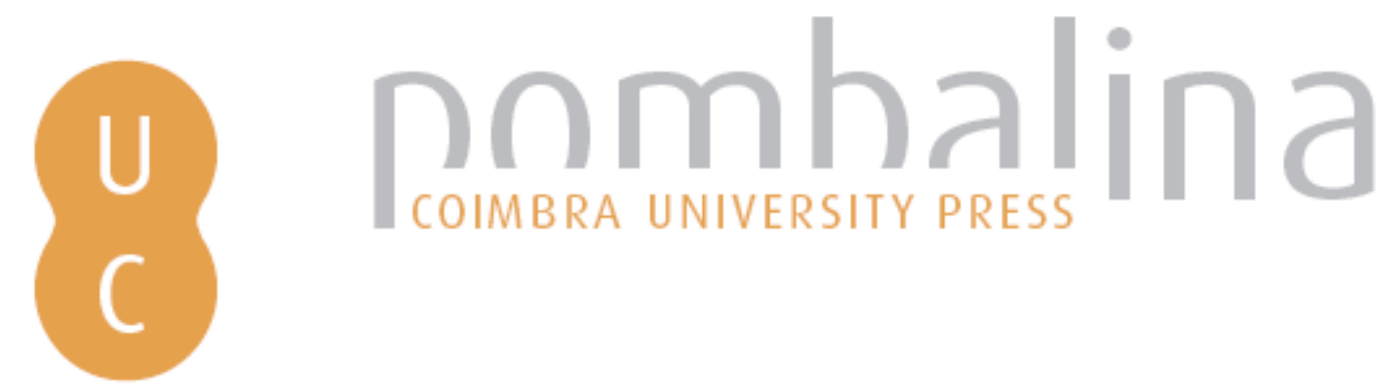

\title{
Veld fire mitigation strategy: a vision for an innovative and integrated approach to managing risks in land reform farms, a case of land reform beneficiaries in South Africa
}

Autor(es): $\quad$ Shwababa, Siviwe Zukile; Restas, Agoston

Publicado por: Imprensa da Universidade de Coimbra

URL persistente:

URI:http://hdl.handle.net/10316.2/44535

DOI:

DOI:https://doi.org/10.14195/978-989-26-16-506_18

Accessed : $\quad$ 26-Apr-2023 03:41:12

A navegação consulta e descarregamento dos títulos inseridos nas Bibliotecas Digitais UC Digitalis, UC Pombalina e UC Impactum, pressupõem a aceitação plena e sem reservas dos Termos e Condições de Uso destas Bibliotecas Digitais, disponíveis em https://digitalis.uc.pt/pt-pt/termos.

Conforme exposto nos referidos Termos e Condições de Uso, o descarregamento de títulos de acesso restrito requer uma licença válida de autorização devendo o utilizador aceder ao(s) documento(s) a partir de um endereço de IP da instituição detentora da supramencionada licença.

Ao utilizador é apenas permitido o descarregamento para uso pessoal, pelo que o emprego do(s) título(s) descarregado(s) para outro fim, designadamente comercial, carece de autorização do respetivo autor ou editor da obra.

Na medida em que todas as obras da UC Digitalis se encontram protegidas pelo Código do Direito de Autor e Direitos Conexos e demais legislação aplicável, toda a cópia, parcial ou total, deste documento, nos casos em que é legalmente admitida, deverá conter ou fazer-se acompanhar por este aviso.

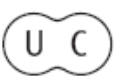




\section{ADVANCES IN}

\section{FOREST FIRE RESEARCH}

\section{8}

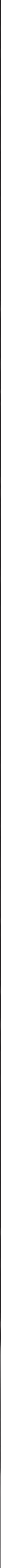




\title{
Veld fire mitigation strategy: A vision for an innovative and integrated approach to managing risks in land reform farms, a case of land reform beneficiaries in South Africa
}

\author{
Siviwe Zukile Shwababa ${ }^{1}$; Agoston Restas ${ }^{2}$ \\ ${ }^{1}$ University of Free State, \{shwababasz@gmail.com\} \\ ${ }^{2}$ National University of Public Service \{restas.agoston@uni-nke.hu\}
}

\begin{abstract}
South Africa has a diverse climate and an equally diverse range of vegetation types, many of which are veld fire-prone. Veld fires form an integral process in many of these ecosystems, and indeed are often necessary for the maintenance of healthy ecosystems and biodiversity. However, in land reform farms headed by land reform beneficiaries veld fires are increasingly viewed and experienced as a destructive force, impacting on crops, livestock, pastures, forestry plantations, human habitation and even on human life.

Land reform beneficiaries are part of the state's programme which seeks to provide the poor and the previously disadvantaged population with land to improve their livelihoods, and also use the land for establishing farming enterprises. These beneficiaries are mostly black emerging farmers, farming with crop and livestock and are largely dependent on the government's recapitalisation programme for the support of their agricultural enterprises. These beneficiaries are faced with various trade-offs and constraints as veld fires expose them to greater risk and renders some of their current practices unworkable. Their vulnerability to veld fires, mitigation, adaptation and coping practices towards veld fires has never been researched before. This study therefore is an attempt to fill this gap.

The management of veld fires within the South African land reform programme, leaves much to be desired and calls for new institutional arrangements and a coordinated approach. This research paper seeks to facilitate veld fire management in land reform farms, through the introduction of measures to combat veld, forest and mountain fires throughout the land reform farms in South Africa and thereby reducing the damage and losses to natural vegetation, life and property. The unequivocal evidence presented in this paper balanced the social, environmental, and economic aspects of veld fires through a risk management strategy that emphasises hazard mitigation, preparedness, and recovery, as well as efficient veld fire response and suppression.
\end{abstract}

Keywords: risk management, veld fires, a veld fire mitigation strategy, hazard mitigation, eco systems, land reform, land degradation

\section{Introduction}

\subsection{Historical context of the land reform programme in South Africa}

The origins of the South African land reform programme can be traced back to 1913, where the previous apartheid government enacted the Native Land Act which became law and served to limit African land ownership to $7 \%$ of the land, consequently increased to $13 \%$ through the 1936 Native Trust and Land Act of South Africa. These legislations restricted indigenous black people from buying or occupying land and gave white people ownership of $87 \%$ of the land. The application of these statutes entrenched discriminatory practices that resulted in land being taken away from black people, until the Commission of Restitution was established in 1994 in order to provide the equitable redress to victims of racially motivated land dispossession (Boudreaux, 2010).

Since 1994, the South African government has been designing and developing a land reform programme that aims to bring about a fair and equitable land dispensation in the country in an orderly 
manner. The land redistribution aspect of the land reform programme focuses on redistributing land to poor black South Africans who need access to land for residential and productive uses, in order to improve their income, quality of life and participation in agricultural production. The Department of Rural Development and Land Reform (DRDLR) is charged with the responsibility of providing previously disadvantaged people access to agricultural land to improve their livelihood, food security, and their quality of life. The department further ensures that beneficiaries placed in land reform farms use farms productively by providing sufficient post settlement support (DRDLR, 2012).

\subsection{Justification and contextualisation of the study}

Almost every winter season, the news media carry stories of veld fires raging across the landscape of the Eastern Cape Province, threatening rural communities, causing evacuations, and sometimes burning public and private property. This portrayal of veldfires as a threat to society is often accurate but it is only part of the story. Veld fires have always and will always be a natural and important phenomenon in environmental systems. However, because of an intensification brought on through anthropogenic activities, fires are having a negative impact on the environment and more so on society and the economy. A large percentage of South Africa's population is located in rural areas; these rural areas are generally situated in fire-prone regions of the country, making them vulnerable to fires (Agri SA, 2017).

Veld fires lead to severe environmental degradation resulting into diminished land cover exposing the land to agents of accelerated soil erosion, changes in the hydrological cycle, increase in overland flow or surface run-off and modifications in various ecological processes. Soil erosion leads to the siltation of rivers and dams, thus reducing their water carrying capacity. This was likely to induce floods in low-lying areas (Kruger, 2006). Severe fires have been revealed to remove surface vegetation and influence soil organic material and peat. This loss of vegetation effectively declines the surface's ability to infiltrate surface run-off after a precipitation event. Fires on mountain slopes have been shown to decrease infiltration by as much as 50\%, thereby increasing the catchment's risk of flash flooding (Agri SA, 2016). Much of the Eastern Cape Province where this study was conducted is vulnerable to severe land degradation because of improper agricultural practices such as overgrazing.

Land degradation in already vulnerable areas may be exacerbated through increased veld fire activity. There are also mountainous regions within the province which are also vulnerable because of the steepness of slopes and the high fire frequencies associated with berg winds (AgriSETA. 2010).

The above-mentioned negative impacts of veld fires posed severe environmental consequences and strain on natural resources. By identifying these areas, those in authority may be able to combat further degradation by limiting veld fire activity and ensuring the prevention of uncontrollable veld fires. Veld fires can also cause injuries to the victims; loss of lives, loss of livelihood assets, health hazards, and moreover a threat to the tourism industry.

The Eastern Cape Province of South Africa is endowed with rich biodiversity where a multitude of fauna and flora exist; fire plays a vital role in the conservation and extinction of many of these species and at times veld fires are a consequence of nature's primary way of keeping the environment (including forests, grasslands, and parks) healthy and productive (Forsyth et al., 2010). Accordingly, policymakers and practitioners are faced with the complex and difficult task of managing veld fires so that their environmental benefits are maximised and simultaneously the risk to people and property is minimised.

Recognising that the contemporary veld fire challenges and those of the future cannot be solved by simply using the thinking and methods of the past. This study proposes a veld fire mitigation strategy which addresses the root causes and the symptoms of veld fires amongst land reform beneficiaries who are farming on land reform farms. It is envisaged that the application of this strategy will increase safety on the land reform farms, improve the health and well-being of the beneficiaries and enhance agricultural production. 


\subsection{The veld fire risk}

A total of about 2500 veld fires were reported during the 2017 fire season in the Eastern Cape province of South Africa, with a majority of fires originating from open flames during waste, grass or bush burnings; some of these fires led to close to fatalities and more than ZAR2 million in financial losses (ECUFPA, 2018). Extensive analysis conducted by the Provincial Disaster Management Centre has found that the vulnerability of people, property, and natural resources to veld fires has reached an unprecedented level and is projected to continue to rise rapidly.

This can be attributed to more frequent and intense veld fires resulting from severe droughts that leave dead and highly flammable fuel load. Meanwhile, current veld fire re-suppression capacity is eroding as facilities and equipment age and experienced fire fighting professionals retire. It is only a matter of time until another major fire season occurs again in the Eastern Cape and the greatest concern is that next time the tragic consequences may include the loss of human lives as seen recently in other parts of the country (PDMC, 2018).

\section{Study area}

The study focused on land reform beneficiaries located and farming in three district municipalities of the Eastern Cape Province, namely Joe Gqabi, Cacadu and OR Tambo District Municipalities.

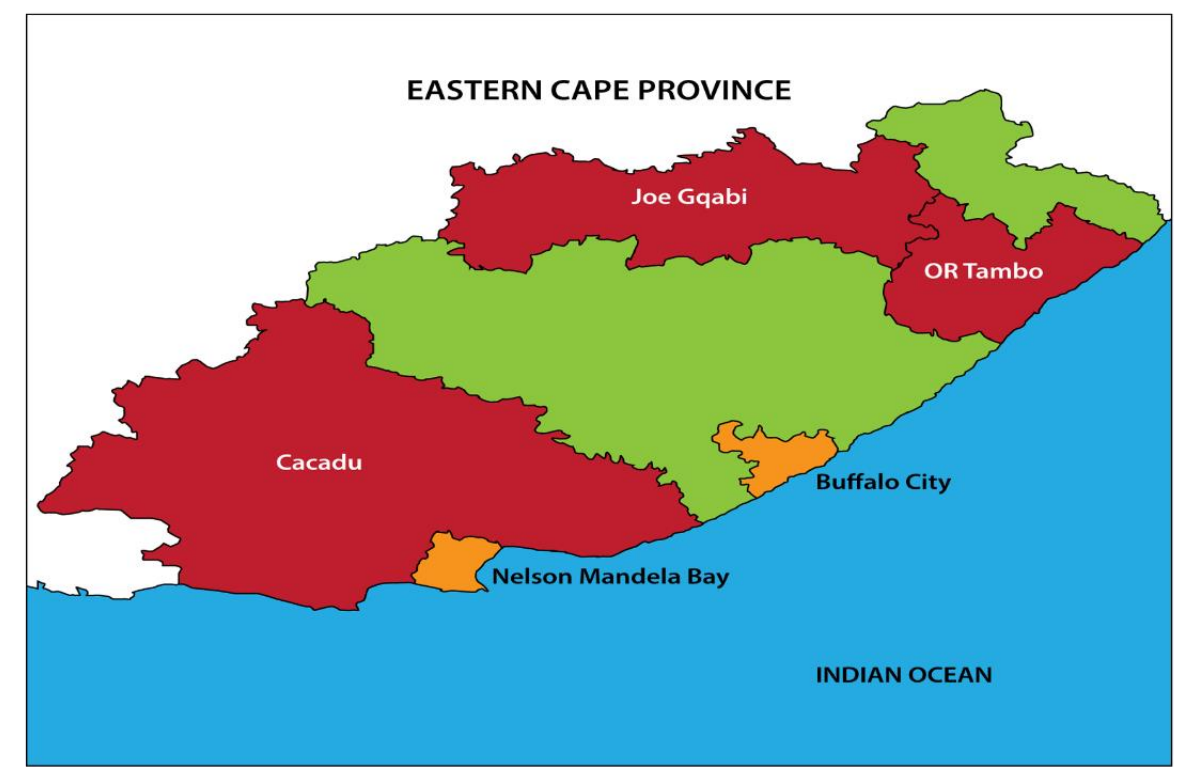

Figure 1 - Map showing the Eastern Cape district municipalities Source: DRDLR (2013)

\section{Methodology}

The aim of this study was to research the effects of veld fires on livelihood assets and agricultural production of land reform beneficiaries and inspire the Department of Rural Development and Land Reform (DRDLR) to develop its own veld fire mitigation strategy that would incorporate preparedness, prevention and mitigation measures for veld fires occurring in land reform farms.

The study was carefully chosen because of practical veld fire related problems encountered within the Land Reform Programme (LRP). For several years, land reform beneficiaries in the Eastern Cape Province have grappled with the far-reaching consequences of various veld fires with no effective plans and mitigation measures. The DRDLR has made no provision for a standard approach to mitigating the effects of veld fires on land reform farms. The current traditional approach towards veld fires is that of crisis management, which is reactive in nature and void of proactive risk reduction 
measures and strategies that will mitigate the devastating impacts of future veld fire events (DRDLR, 2013).

The LRP has no documented model to strengthen the absorptive, adaptive and transformative capacities of vulnerable beneficiaries to cope with and recover from the effects of veld fires (Mock et al., 2015).

The Participatory Learning Action (PLA) technique was used as a data collection tool in this study. Workshops were conducted in all of the three study sites where land reform beneficiaries participated. Through the PLA technique the respondents acquired a platform to, for the first time, articulate their own narratives (in their own language) regarding the extent of veld fires they experienced and the impact these had on their livelihoods and agricultural production. The usage of the PLA technique empowers local people by giving them opportunities to express and enhance their knowledge and take action (Chambers, 2008; Bunce et al., 2010). Through the PLA technique respondents were afforded an opportunity to draw a mental map reflecting shocks which had a negative effect on their livelihoods and agricultural production. Mental maps are useful tools which help to 'visualise' the complex reality people deal with in their day-to-day lives (SEAGA, 2001; Wilde 2001). In these mental maps the respondents were also able to highlight the causes and effects of the said shocks. A word frequency analysis method was used as part of the PLA technique and it revealed the extent and severity of veld fires in each study site. The analysis was carried out using correspondence analysis by Abdi and Béra (2014). The observation of the veld fire phenomenon in some of the study sites was a useful data collection method, which culminated into a successful research project.

\section{Results}

In drawing up their mental map, the respondents specified veld fires as one of the shocks which have an effect on their farming enterprises. The root cause was attributed to the lack of firebreaks and dry weather conditions, with loss of livestock and damage to property as resultant effects. Drought was also depicted as a shock alongside veld fires, thus endorsing a commonly held view by several scientists that there is a very close relationship between drought and veld fires (Wilhite et al., 2014). Drought conditions make the vegetation to dry out quicker and with no rains due to drought before a fire, the rate of spread for veld fires becomes considerably higher.

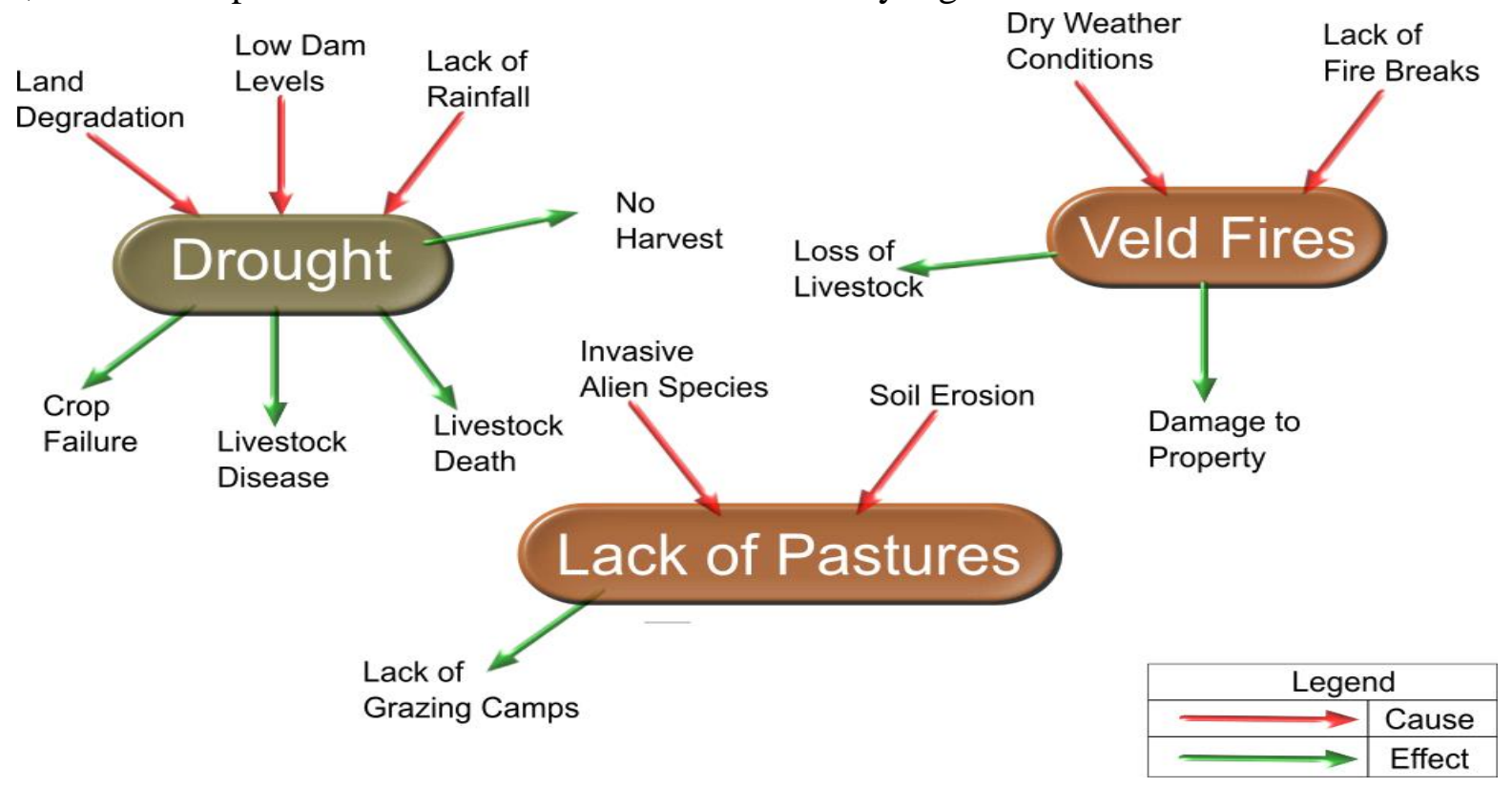

Figure 2 - Mental map 
Another finding portrayed by respondents through mental maps was lack of pastures caused by soil erosion and invasion of alien species. This finding concurs with the IPCC (2014) who pointed out that wherever veld fires occur, they turn to culminate into to severe environmental degradation. More explicitly, veld fires lessen land cover, thus uncovering the land to agents of fast-tracked soil erosion, changes in the hydrological cycle, escalation in overland flow or surface run off and alterations in a number of ecological processes (Lynn, 2014). The presence of alien species perpetuates the spread of veld fires, reducing the aesthetic value of the natural land and causing a strain on natural resources. Fires do provide an environmental service and are an integral part in the maintenance of the ecosystem; however, increased veld fire activity, brought about by anthropogenic action, leads to adverse effects in the environment.

The word frequency analysis method contributed to revealing the extent and severity of veld fires in each study site. Through the ranking process it further exposed the importance associated with the mentioned shock. This gave a clear overview in terms of the manner in which veld fires affected the livelihoods and agricultural production of the land reform beneficiaries in the study sites.

\section{Shocks: Veld Fires}

Frequency Mentioned (1-4)
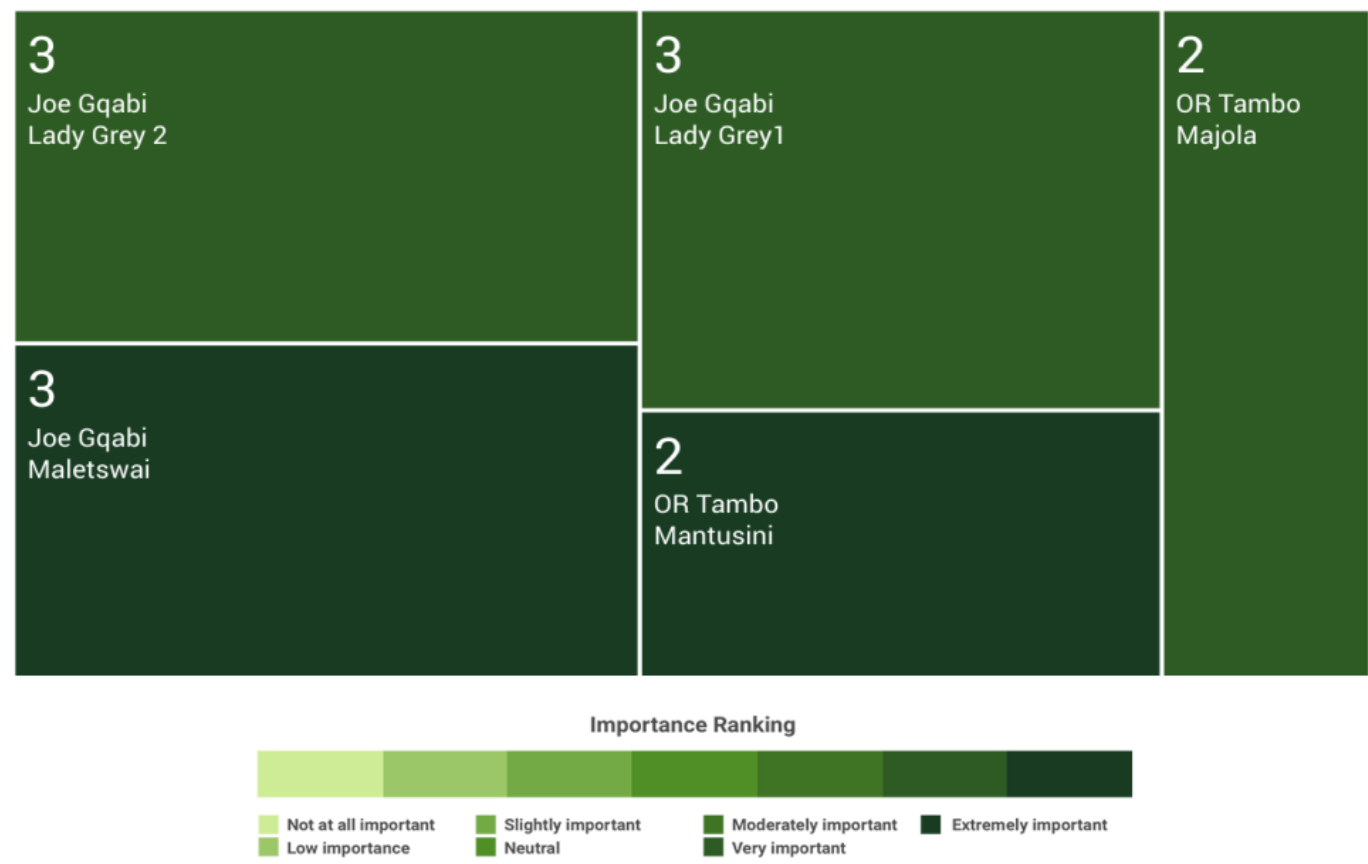

Figure 3 - Tree map word frequency analysis of 'veld fires'

As illustrated in Figure 3, the shock of 'veld fires' was of major concern in Maletswai, based on the number of times they were mentioned and ranked in terms of importance. In Lady Grey 1 and Lady Grey 2 veld fires were of a concern, although at a lower ranking, compared to Maletswai, Mantusini and the Majola Tea Estate that shared the value in terms of the frequency that the shock was cited; however, it was different in terms of how it was ranked. In Mantusini, veld fires were of a significantly higher ranking compared to that of the Majola Tea Estate.

During the 2016 fire season, the land reform beneficiaries of the Majola Tea Estate were captured by the local press extinguishing veld fires without the necessary fire fighting equipment. The article entitled "Majola Tea Estate workers spent about five hours trying to extinguish a fire which engulfed at least 35 hectares of the tea fields, resulting in a loss estimated to run into millions of rands" (Ntshobane, 20 July 2016). 


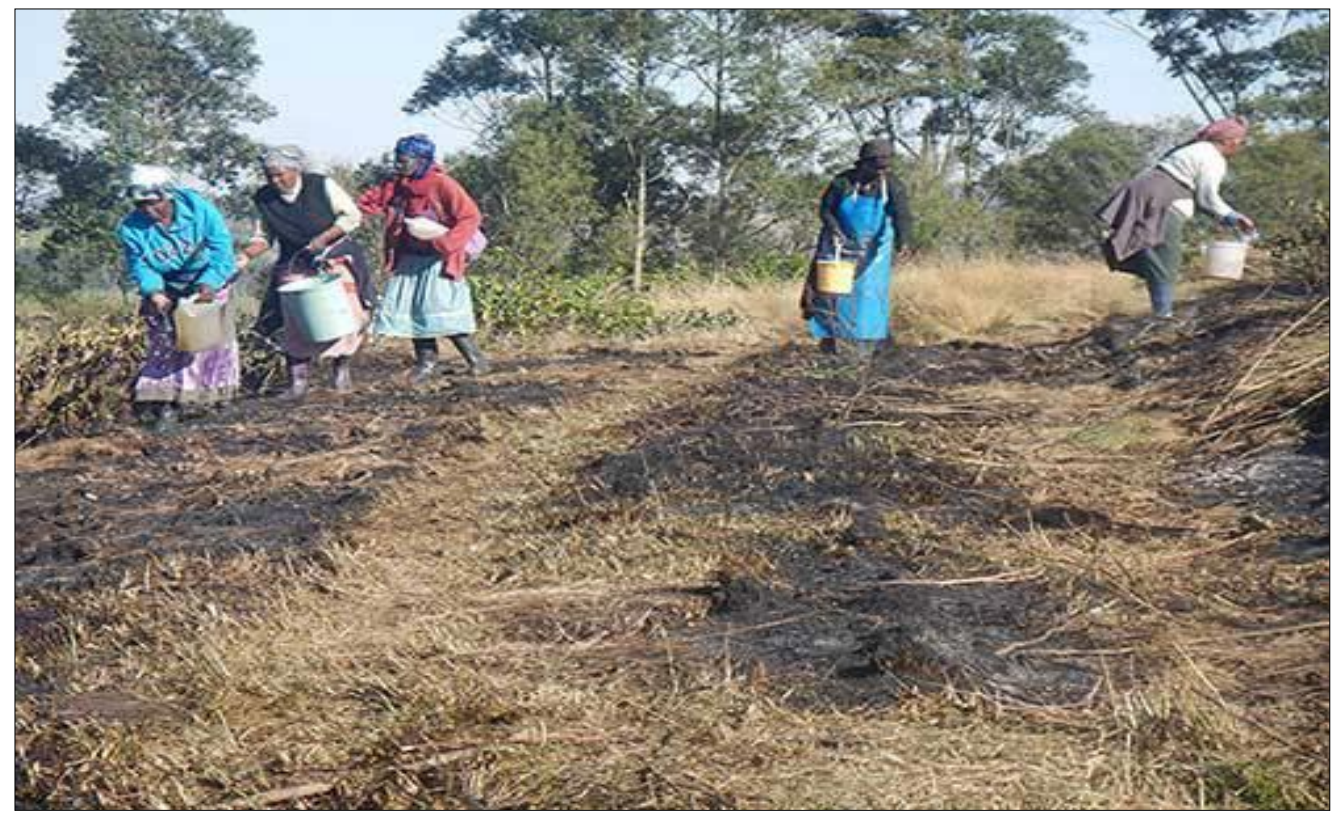

Figure 4 - Majola Tea Estate beneficiaries trying to extinguish a veld fire. Source: Ntshobane (2016)

The above finding depicts land reform beneficiaries attempting to extinguish veld fires without the necessary equipment and apparatus, thus exposing their health to the adverse effects of veld fires. This is because veld fires are comprised of carbon dioxide and water vapour, combined with the hazardous chemicals released from the burning of land fuels. The inhalation of smoke from a veld fire could therefore cause a significant health hazard (NOAA, 2014).

Veld fires have been classified as one of South African hazards which often lead to disasters, resulting in both loss of human and animal life and loss of property. The results of this study provide an insight into the effect of veld fires on livelihoods and agricultural production of land reform beneficiaries. In order for fire disasters to be mitigated within the land reform programme, the DRDLR as the landowner and government decision-makers need to ensure an efficient and effective allocation of resources, including human resources, to limit the spread of veld fires and to ensure that veld fires do not result in adverse effects on the environment and society. In order for the land reform beneficiaries to be resilient against future veld fire disasters, there needs to be a better understanding of high risk areas. This study has made way for further investigation into high risk vulnerable areas of the South African land reform programme.

\section{Proposed innovative veld fire mitigation strategy}

Figure 5 depicts the proposed innovative veld fire mitigation strategy for land reform beneficiaries. The strategy consists of five themes, the collective application of these themes will result into proper management of veld fire risks within land reform farms and sustainable livelihoods and agricultural production. 


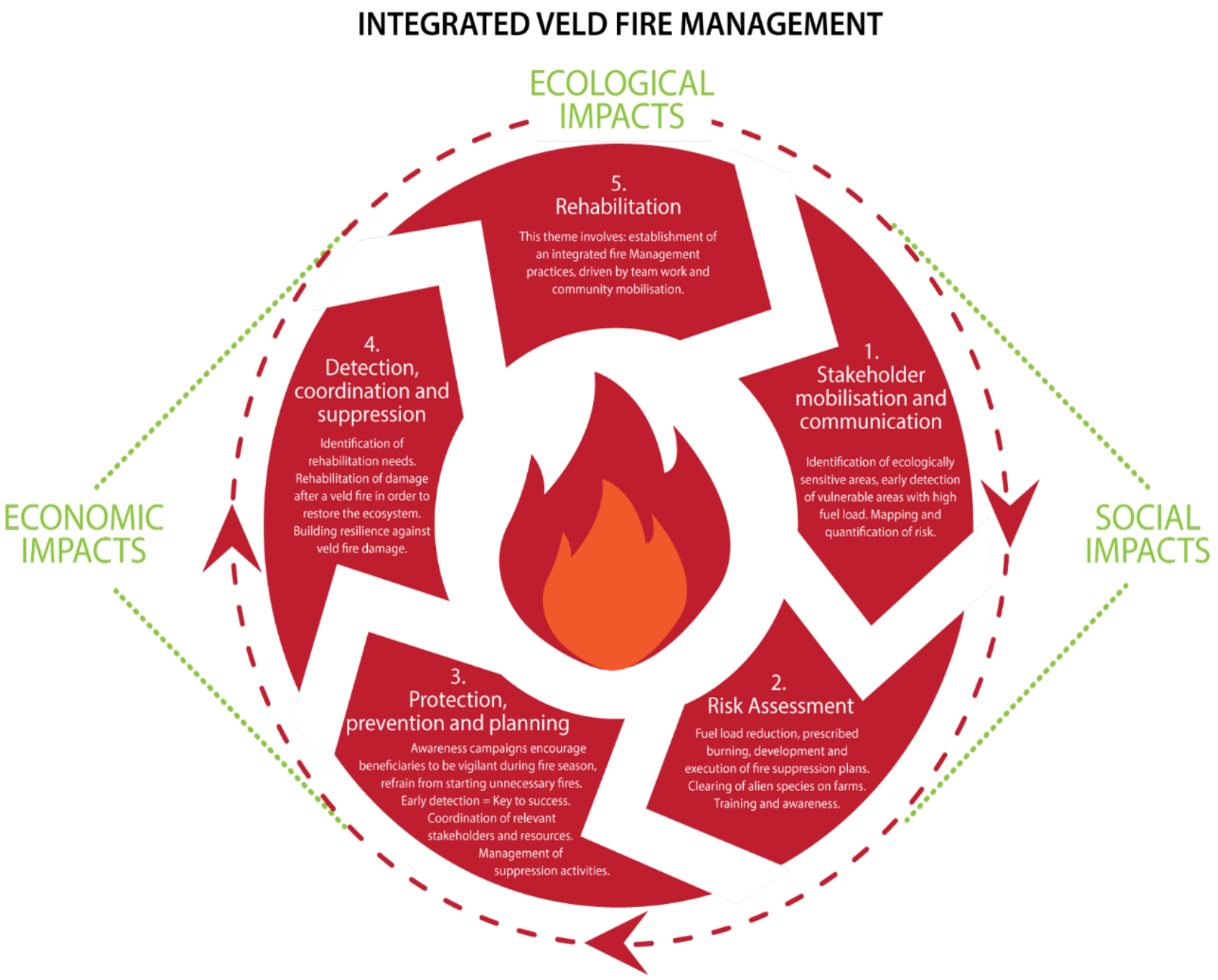

Figure 5 - Proposed innovative veld fire mitigation strategy

\section{Conclusion}

The results provided confirm the need for a veld fire mitigation strategy within the land reform programme. The strategy will boost active involvement thus strengthening capacity to cope with veld fires in land reform farms and improve livelihood security. Additionally, the strategy will assist in determining on farm infrastructure under threat from veld fires and vulnerable areas where there is an abundance of fuel that can start veld fires.

\section{References}

Abdi, H. \& Béra, M. 2014. Correspondence analysis. In R. Alhajj \& J. Rokne (eds.), Encyclopedia of social networks and mining (275-284). New York: Springer Verlag. (Preprint available at https://www.utdallas.edu/ herve/abdi-AB2014_CA.pdf)

Agri SA. 2016. A raindrop in the drought. Report to the multi-stakeholder task team on the drought. Agri SA's status report on the current drought crisis. Available at http://www.nstf.org.za/wpcontent/uploads/2016/06/Agri-SA-Drought-Report_CS4.pdf (Accessed 3 May 2018). 
Agri SA. 2017. Land audit: A transactions approach. Pretoria. Available at https://www.agrisa.co.za/wp-content/uploads/2017/11/AgriSA_Land-Audit_November-2017.pdf (4 June 2018)

AgriSETA. 2010. Sector analysis: Agriculture. Pretoria. Available at http://www.agriseta.co.za/downloads/news/AGRISETA_Sector_Analysis_290610-version_2.pdf (5 June 2018...)

Boudreaux, K. 2010. Land reform as social justice. Institute of Economic Affairs, 30(1):13-20.

Bunce, M., Rosendo, S., Brown, K. 2010. Perceptions of climate change, multiple stressors and livelihoods on marginal African coasts. Environment, Development and Sustainability, 12:407-440.

Chambers, R. 2008. PRA, PLA and pluralism: practice and theory. In P. Reason \& H. Bradbury (eds.). The Sage handbook of action research: participative inquiry and practice. London: SAGE.

CSIR. 2010. Natural resources and the environment, national veldfire risk assessment: Analysis of exposure to social, economic and environmental assets to veldfire in South Africa, Stellenbosch.

DLRLR (Department of Rural Development and Land Reform). 2012. Land Reform Policy Discussion Document. Pretoria.

DRDLR (Department of Rural Development and Land Reform). 2013. Policy for the Recapitalisation and Development Programme of the Department of Rural Development and Land Reform. Pretoria.

ECUFPA. 2018. Integrated Fire Management Report. Easter Cape Umbrella Fire Protection Association. Stutterheim.

Forsyth, G., Kruger, F.G. \& Le Montre, C.G. 2010. National veldfire risk assessment: Analysis of exposure of social, economic and environmental assets to veldfire hazards. Available at: http://www.ehs.unu.edu/file/get/5254 (Accessed 26 June 2018)

Intergovernmental Panel on Climate Change (IPCC). Summary for policy makers. In: Climate change 2014: Impacts, adaptions, and vulnerability. Part A: Global and sectoral aspects. Contribution of Working Group II to the Fifth Assessment Report of the IPCC. Cambridge, UK: Cambridge University Press; 2014. p. 1-32. http://dx.doi.org/10.1017/CBO9781107415416.005

Kruger, F.J., Forsyth, G.G., M Kruger, L.G., Slater, K., Le Maitre, D.C. \& J Matshate, J. 2006.

International Conference on forest fire research: Classification of Veldfire Risk in South Africa for the Administration of the Legislation regarding Fire Management [Online]. Retrieved from: http://www.ehs.unu.edu/file/get/5254 html [2018, June 26].

Mock, N., Béné, C., Constas, M. \& Frankenberger, T. 2015. Systems cluster paper: Systems analysis in the context of resilience. For discussion at the meeting on Resilience Measurement Technical Briefings. Resilience Measurement Technical Working Group. Rome: FSIN.

NASA image courtesy Jeff Schmaltz, MODIS Rapid Response Team. Caption: NASA/Goddard, Lynn Jenner with information from the Volunteer Wildfire Services in South Africa, and Weather South Africa. [Online] Retrieved from: http://www.nasa.gov/content/goddard/veld-fires-in-south-africa/ html (Accessed 28 May 2018)

National Oceanic and Atmospheric Administration (NOAA). Climate at a glance. National Climate Data Centre. Available at: http://www.ncdc.noaa.gov/cag/time-series/global (Accessed 11 May 2018)

Ntshobane, S. 2016. Workers battle to kill fire at Majola tea estate. Dispatch LIVE, 20 July 2016. Available online at https://www.dispatchlive.co.za/news/2016-07-20-workers-battle-to-kill-fire-atmajola-tea-estate/

PDMC (Provincial Disaster Management Centre). 2018. Provincial fire status quo report, 2018 fire season. Provincial Disaster Management Centre. Bhisho. 
Socio-economic and Gender Analysis (SEAGA) Programme. 2001. Field level handbook. Food and Agriculture Organization (FAO) of the United Nations, Italy, Rome.

Wilde, V. 2001. Socio-economic and gender analysis (SEAGA) programme. Gender and Development Service. Handbook. Published by FAO (Food and Agriculture Organisation of the United Nations).

Wilhite, D.A., Sivakumar, M.V. and Pulwarty, R. 2014. Managing drought risk in a changing climate: The role of national drought policy. Weather and Climate Extremes, 3:4-13. 